\title{
Self Efficacy Of Mother Working In Giving Mother Milk Water With Baby Growth
}

\author{
Monika Sawitri Prihatini, Ririn Probowati, Mamik Ratnawati \\ STIKES Pemkab Jombang, East Java, Indonesia \\ Corresponding author: monika.sawitri@yahoo.co.id
}

\begin{abstract}
Background: The paradigm change that there is no difference between men and women demands equal rights between women and men. Many mothers work as career women, so many women replace breastfeeding with formula milk. Based on indonesian government regulations No. 33 of 2012, a mother is obliged to give exclusive breastfeeding to her baby.

Purpose: This study aimed to determine the relationship between self-efficacy of working mothers in breastfeeding and infant growth.

Method: The type of correlational analytic research is a cross-sectional approach. The population and sample of working mothers who have babies aged 0-6 months on May 9 to June 6, 2018, at PT Mufasufu Sejati Jaya Lestari MPS Ploso are 30 respondents with a total sampling technique. Independent variable Self Efficacy for working mothers in breastfeeding, the dependent variable for infant growth. The growth instrument uses a standard table of body weight/body length from the Ministry of Health and a Self Efficacy questionnaire for mothers to provide breastfeeding. Data analysis using chisquare.

Results The results of the Chi-Square test analysis at the significance level of $\alpha=0.05$ found that $\rho<\alpha$ or $0.048<0.05$, there is a relationship between self-efficacy of mothers working in breastfeeding and growth in infants.

Conclusion: The head of the agency/company must provide nursing mothers with exclusive breastfeeding by providing a lactation corner so that the mother can milk the milk and store it in the freezer in the refrigerator and take it home to give to the baby while the mother is working so that the baby continues to get milk without formula milk.
\end{abstract}

Keywords: Maternal Self Efficacy, Breastfeeding, Baby Growth

Received July, 25, 2019; Revised August 24, 2019; Accepted September 13, 2019

How to Cite: Prihatini, M. S., Probowati, R., Ratnawati, M. (2019). Self Efficacy Of Mother Working In Giving Mother Milk Water With Baby Growth. Journal Of Nursing Practice, 3(1), 1-7.

https://doi.org/10.30994/jnp.v3i1.74 


\section{BACKGROUND}

The rights of mothers as workers are regulated in Law No. 13 of 2003 concerning employment, namely: obtaining resting leave for 1.5 months before and 1.5 months after childbirth (Article 82) and female workers whose children are still breastfeeding should be given the opportunity to breastfeed their child if it must be done during work time ( Article 83) (Nurjanah, 2008). Policies that apply in companies often do not support women's rights, with shortened maternity leave and no opportunity for female workers to breastfeed their children during working hours. Working mothers can only accompany their babies intensively for 2 (two) months, after which the mother must return to work, and often the mother is forced to stop breastfeeding.

Table 1. Percentage of breastfeeding coverage in Jombang Regency

\begin{tabular}{cc}
\hline Year & Percentage \\
\hline 2010 & $53,4 \%$ \\
\hline 2011 & $79,4 \%$ \\
\hline 2012 & $71,87 \%$ \\
\hline 2015 & $83,3 \%$ \\
\hline 2016 & $81,7 \%$ \\
\hline
\end{tabular}

Source: District Health Office Jombang

Mother's milk is the best natural nutrition for babies because it contains energy and substance needs needed during the first six months of a baby's life. The level of breastfeeding can be influenced by several factors. One of them is due to the factor of working mothers. Many mothers work as career women. Indonesia is a country that absorbs much labor from mothers as well as a country with a very low number of mothers who provide breast milk (Prasetyono, 2009).

Factors that hinder the success of breastfeeding in working mothers are short time off work, lack of workplace support, short break time at work so that the time to milk Mother's Milk is not enough, there is no room for milking Mother's Milk, the mother's contradiction between maintaining work performance and production of Mother's Milk I (IDAI, 2010).

The role of the mother working in the administration of Mother's Milk I is very determined by the mother's self-efficacy Self efficacy is someone's belief about their ability to regulate and decide on certain actions needed to obtain certain results. In general, self-efficacy is a person's assessment of himself or the level of confidence regarding how much his ability to do a particular task (Bandura, 1997). People who have low self-efficacy always consider themselves unable to handle any situation while those who have high self-efficacy tend to show more effort than others with low selfefficacy in breastfeeding.

Child development is influenced by internal and external factors. One of the postnatal factors is nutrition. Nutritional elements become the dominant influence in the growth of children, especially at the beginning of life until the age of 12 months. The nutrients needed by babies can be fulfilled by giving Mother's Milk. Mother's milk is the optimal choice as feeding in infants because of the nutritional, hormone, immune factors, growth factors, and anti-inflammatory factors (Fitri et al., 2014).

Health promotion from health workers is expected to improve a person's selfefficacy in the form of verbal persuasion to provide breast milk appropriately and correctly. It is not only the skills that a mother has but the decisions that someone takes 
are the mother of the skills she has. Through this positive attitude, it will eventually be manifested in the form of real behavior in the effort to provide breast milk. The concept of thinking is in line with the formation of behavior preceded by attitudes, while attitudes in precedence of knowledge (Hidajaturrokhmah, 2016).

\section{OBJECTIVE}

This study aimed to determine the relationship between self-efficacy of working mothers in breastfeeding and infant growth.

\section{METHODS}

The type of research used is a correlational analytic cross-sectional approach. The population and sample of the study were all mothers who worked at PT Mufasufu Sejati Jaya Lestari MPS Ploso who had babies aged 0-6 months and breastfed as many as 30 people. The sampling technique used is non-probability sampling with the Total Sampling method. The independent variable in this study is the mother's Self Efficacy in breastfeeding. The dependent variable in this study is infant growth. The instrument used was the standard bodyweight/length table from the Ministry of Health in 2016 and a questionnaire for the mother's Self Efficacy in providing Mother's Milk. Analysis of bivariate data was carried out on two variables performed by chi-square testing.

The participants were assured that their engagement was voluntary, and that anonymity, privacy, and confidentiality of the data were guaranteed. Furthermore, they were informed about the purpose and the method of the study before signing a written informed consent. The questionnaires were distributed to eligible participants at the PT Mufasufu Sejati Jaya Lestari MPS Ploso, and respondents were asked to complete and return them in the same time.

\section{RESULT}

a. Univariate result

Table 2. Distribution of self-efficacy frequencies from working mothers in breastfeeding).

\begin{tabular}{|c|c|c|}
\hline Self Efficacy & f & Percentage (\%) \\
\hline High & 12 & 40 \\
\hline Medium & 14 & 46,7 \\
\hline Low & 4 & 13,3 \\
\hline Total & 30 & 100 \\
\hline
\end{tabular}

Based on the table it is known that almost half (46.7\%) working mothers have moderate self-efficacy in breastfeeding infants aged 0-6 months.

Table 3. Baby growth frequency distribution based on nutritional status

\begin{tabular}{ccc}
\hline $\mathbf{B B} / \mathbf{P B}$ & $\mathbf{f}$ & $\mathbf{( \% )}$ \\
\hline Obesity & 7 & 23,3 \\
Over Weight & 13 & 43,3 \\
Normal & 10 & 33,4 \\
Total & 30 & 100 \\
\hline
\end{tabular}


Based on the table, it can be seen that the growth of infants based on nutritional status is almost Over weight (43.3\%), almost half are $33.4 \%$ normal and $23.3 \%$ are obesity.

b. Bivariate result

Table 4. Cross Tabulation between Mother's Self Efficacy and baby's growth

\begin{tabular}{|c|c|c|c|c|c|c|c|c|}
\hline \multirow{3}{*}{ Self Efficacy mother } & \multicolumn{8}{|c|}{ Growth (Nutritional status) } \\
\hline & \multicolumn{2}{|c|}{ Obesity } & \multicolumn{2}{|c|}{$\begin{array}{l}\text { Overwei } \\
\text { ght }\end{array}$} & \multicolumn{2}{|c|}{ Normal } & \multicolumn{2}{|c|}{ Total } \\
\hline & $\mathbf{f}$ & $\%$ & $\mathbf{f}$ & $\%$ & $\mathbf{f}$ & $\%$ & f & $\%$ \\
\hline Low & 1 & 3,3 & 1 & 3,3 & 2 & 6,7 & 4 & 100 \\
\hline Medium & 0 & 0 & 8 & 26,7 & 6 & 20 & 14 & 100 \\
\hline High & 6 & 20 & 4 & 13,3 & 2 & 6,7 & 12 & 100 \\
\hline Total & 7 & 23,3 & 13 & 43,3 & 10 & 33,4 & 30 & 100 \\
\hline
\end{tabular}

Based on the table shows that working mothers who have moderate self-efficacy in breastfeeding have babies with growth with nutritional status in the category of Over Wight as much as $26.7 \%$

Table 5. Cross-tabulation between self-efficacy of mothers working in breastfeeding with breastfeeding

\begin{tabular}{lcccccc}
\hline \multirow{3}{*}{ Self Efficacy mother } & \multicolumn{5}{c}{ Giving Breast Milk } \\
\cline { 2 - 8 } & $\begin{array}{c}\text { Exclusive } \\
\text { breastfeeding }\end{array}$ & $\begin{array}{c}\text { Nonexclusive } \\
\text { breastfeeding }\end{array}$ & Total \\
\cline { 2 - 8 } & $\mathbf{f}$ & $\mathbf{\%}$ & $\mathbf{f}$ & $\mathbf{\%}$ & $\mathbf{f}$ & $\mathbf{\%}$ \\
\hline Low & 0 & 0 & 4 & 13,3 & 4 & 100 \\
\hline Medium & 5 & 16,7 & 9 & 30 & 14 & 100 \\
\hline High & 6 & 20 & 6 & 20 & 12 & 100 \\
\hline Total & 11 & 36,7 & 19 & 63,3 & 30 & 100 \\
\hline
\end{tabular}

Based on the table above shows that mothers who have self-efficacy are giving nonexclusive breastfeeding to their babies as much as $30 \%$.

Based on the analysis using Chi-Square test at significance level $\alpha=0.05$, it was found that $\rho<\alpha$ or $0.048<0.05$, H1 was accepted and H0 was rejected which means there is a Self Efficacy Relationship between working mothers in breastfeeding and growth in infants 0-6 months at PT Mufasufu Sejati Jaya Lestari MPS PlosoBased on the analysis using Chi-Square test at significance level $\alpha=0.05$, it was found that $\rho<\alpha$ or $0.048<0.05, \mathrm{H} 1$ was accepted and $\mathrm{H} 0$ was rejected which means there is a Self Efficacy Relationship between working mothers in breastfeeding and growth in infants 0-6 months at PT Mufasufu Sejati Jaya Lestari MPS Ploso. 


\section{DISCUSSION}

Based on the above results show that working mothers who have moderate selfefficacy in breastfeeding have babies with growth with a Over Weight category as much as $26.7 \%$. Based on research conducted at the Nanggolo Community Health Center in 2014, it was found that infants who were given exclusive breastfeeding would experience normal growth of 1.62 times greater than non-exclusive breastfed babies (Fitri et al., 2014). Research carried out at the Manado Manado Puskesmas in 2016 found that more weight babies who received exclusive breastfeeding were lighter than infants who received formula milk until the age of 6 months.

Exclusive breastfeeding is the right choice that can control the baby's nutritional needs so that the baby's weight tends not to be obese (Lutur et al., 2016). In the opinion of mothers, researchers who have moderate self-efficacy towards breastfeeding give their babies with non-exclusive breastfeeding. Mothers continue to give breast milk but mixed with formula so that the baby's weight tends to be Over Weight. Mothers give formula milk while working while breast milk is given when the mother is at home. This statement is proven in Table 8 . Based on this table, it shows that mothers who have self-efficacy are giving non-exclusive breastfeeding to their babies as much as $30 \%$.

Based on the analysis using Chi-Square test at significance level $\alpha=0.05$, it was found that $\rho<\alpha$ or $0.048<0.05, \mathrm{H} 1$ was accepted and $\mathrm{H} 0$ was rejected which means there is a Self Efficacy Relationship between working mothers in breastfeeding and growth in infants 0-6 months at PT Mufasufu Sejati Jaya Lestari MPS Ploso. Not only research in Indonesia, but a study in Baltimore Washington also found that infants who were given exclusive breastfeeding were of normal weight and were not obese compared to infants who received non-exclusive breast milk (Fitri et al., 2018).

Bandura's theory of health promotion model consists of components, among others, Expectancy value theory, and interaction model theory, which includes the environment, human, and behaviors that influence each other. This theory emphasizes self-direction (self-direction), self-regulation (self-regulation), perception of selfprogress (self-efficacy). This theory suggests that humans have basic abilities, among others, symbolizing namely the process and transformation of experience as a guide for future actions, future thoughts, anticipating events that will emerge and planning actions to achieve quality goals, students from other people's experiences (Probowati, 2016) Based on table 7 shows that working mothers who have moderate self-efficacy in breastfeeding have babies with growth with a Over Weight category as much as $26.7 \%$. Based on research conducted at the Nanggolo Community Health Center in 2014, it was found that infants who were given exclusive breastfeeding would experience normal growth of 1.62 times greater than non-exclusive breastfed babies (Fitri et al., 2014). Research carried out at the Manado Manado Puskesmas in 2016 found that more weight babies who received exclusive breastfeeding were lighter than infants who received formula milk until the age of 6 months.

Exclusive breastfeeding is the right choice that can control the baby's nutritional needs so that the baby's weight tends not to be obese (Lutur et al., 2016). In the opinion of mothers, researchers who have moderate self-efficacy towards breastfeeding give their babies with non-exclusive breastfeeding. Mothers continue to give breast milk but mixed with formula so that the baby's weight tends to be Over Weight. Mothers give formula milk while working while breast milk is given when the mother is at home. 
This statement is proven in Table 8. Based on this table, it shows that mothers who have self-efficacy are giving non-exclusive breastfeeding to their babies as much as $30 \%$.

Based on the analysis using Chi-Square test at significance level $\alpha=0.05$, it was found that $\rho<\alpha$ or $0.048<0.05$, H1 was accepted and H0 was rejected which means there is a Self Efficacy Relationship between working mothers in breastfeeding and growth in infants 0-6 months at PT Mufasufu Sejati Jaya Lestari MPS Ploso. Not only research in Indonesia, but a study in Baltimore Washington also found that infants who were given exclusive breastfeeding were of normal weight and were not obese compared to infants who received non-exclusive breast milk (Fitri et al., 2018).

Bandura's theory of health promotion model consists of components, among others, Expectancy value theory, and interaction model theory, which includes the environment, human, and behaviors that influence each other. This theory emphasizes self-direction (self-direction), self-regulation (self-regulation), perception of selfprogress (self-efficacy). This theory suggests that humans have basic abilities, among others, symbolizing namely the process and transformation of experience as a guide for future actions, future thoughts, anticipating events that will emerge and planning actions to achieve quality goals, students from other people's experiences (Probowati, 2016)

\section{CONCLUSION}

There is a relationship between self-efficacy of working mothers in breastfeeding and infant growth. Working mothers who have moderate self-efficacy tend to give non-exclusive breastfeeding to infants aged 0-6 months. When mothers at home, babies get breast milk, but when working mothers babies are given formula milk so that babies have growth with nutritional status in the Over weight category.

\section{REFERENCES:}

Bandura, A. 1997. Self efficacy: The Exercise of control. New York. W. H. Freeman

Baron \& Byrne. 2003. Psikologi Sosial. Jilid 1 Edisi Kesepuluh. Jakarta: Erlangga

Fitri Insana Dian, dkk. 2014. Hubungan Pemberian ASI dengan Tumbuh Kembang Bayi Umur 6 bulan di Puskesmas Nanggolo. Jurnal Kesehatan Andalus. 3(2)

Hambawany, E. 2007. Hubungan antara Self Efficacy dan Persepsi Anak Terhadap Perhatian Orangtua Dengan Prestasi Belajar pada Penyandang Tuna Daksa. Skripsi (tidak diterbitkan). Fakultas Psikologi: Universitas Muhammadiyah Surakarta.

Hidajaturrokhmah, N., \& Saputro, H. (2016). Pertumbuhan Berat Badan Bayi Usia 6 Bulan Ditinjau Dari Jenis Nutrisi. STRADA Jurnal Ilmiah Kesehatan, 5(1), 38-45. Retrieved from http://strada.ac.id/sjik/index.php/sjik/article/view/102

IDAI. 2010. Indonesia Menyusui. Jakarta: Badan Penerbit IDAI 
Nurjanah.2008. Implementasi Pasal Undang-undang No 13 Tahun 2003 Tentang Hak Menyusui Pekerja Perempuan Selama Bekerja. Jurnal Promosi Kesehatan Indonesia, 3(1).

Prasetyono. 2009. Buku Pintar ASI Eksklusif, Pengenalan Praktik dan Kemanfaatannya. Jogjakarta: Diva Press

Probowati, Ririn. 2016. Model Keperawatan Role Attainment Ibu Bekerja Dengan Pendekatan Self Efficacy Dalam Kompetensi Stimulasi Pertumbuhan Dan Perkembangan Bayi. Surabaya : Desertasi

Soetjiningsih. 2014. Tumbuh Kembang Anak. Jakarta: EGC

Yuliarti, Nurheti. 2010. Keajaiban ASI : Makanan Terbaik untuk Kesehatan, Kecerdasan dan Kelincahan Si Kecil. Yogyakarta 